\title{
African Indigenous Knowledge: The Challenges of Industrialization
}

\author{
Dr Adigbuo Ebere Richard
}

Nigeria

\begin{abstract}
Africa remains a contested domain geographically and academically. In substance, Africa does not necessarily mean the same thing to everyone. The same applies to Africa as an object of study. Following the scramble for Africa, the continent experienced an unfortunate incursion and distortion of its indigenous knowledge. With the incorporation of the continent into the western capitalist world and academy, most of what is African is lost. Today, it is difficult for Africa to keep pace with its home grown technologies. It is even more difficult to ask the West, as a show of charity, to transfer its technologies to Africa. But since knowledge, whether indigenous or western, has some utilitarian values, it is essential to address the African socio-economic problems through a knowledge driven economy. There is the need for Africa to be industrialized. This study recommends the Japan's model that combined an indigenous knowledge system with the Western scientific discoveries to Africa.
\end{abstract}

Keywords: Colonization, Indigenous Knowledge, Scientific Invention, Industrialization, Africa, Japan.

\section{INTRODUCTION}

Many Europeans that came to Africa conceived the continent as one without history. This perception to say the least was quite inappropriate and ill-conceived. Europe thus exhibited an ignorance of the African knowledge systems which partly explains why the formal established European schools never took any consideration of the informal educational system that pervaded the entire continent, a system of education through which knowledge was transmitted from one community to another, and from one generation to another. The basic thrust was that the Europeans introduced something totally new. Disparaging the African indigenous learning processes presupposes non existence of social interaction or socialization among African societies; it also implied that the Africans had no system in place to bring their offspring in accordance with African demands and cultures. The perception is sad. There were other groups who regarded reading and writing, as the main basis of education. To these groups, reading and writing is synonymous with Western civilization. The Western attitude was a deliberate one to eradicate anything African including its system of transmitting knowledge to its young ones. Western institutions were introduced to undermine the African ways of life and definitely paved the way for their replacements. It is on this note that some analysts interpreted the missionary activities of Europe as a "frontal attack on the beliefs, customs, apprehensions of life and the work and by implication... on the social structures and bases of primitive [African] society" (Kraemer, 1938:230). To execute the colonial agenda, African names were replaced with the European ones and English became the medium of teaching to the exclusion of the local languages in the Anglo-speaking African states. This reminds one of Jones incisive remark that no greater injustice can be committed against a people than to deprive them of their own language (Jones, 1924). Besides the renunciation of native names, African religions were derided. Africans were inducted to ape European Christian values. Every African must be initiated into the western values at baptism, a process that made some Africans like Mbonu Ojike, to decry his father's religion as 'heathen', and of course "inferior to the white man's" (Berman, 1975). Today, virtually in every sector, the Western system of life and culture has replaced the African indigenous values and knowledge.

Quite unfortunately, it is the same Africa that produced classical bronzes of Igbo Ukwu in the $9^{\text {th }}$ century, that of Ife (from $11^{\text {th }}$ to $12^{\text {th }}$ century AD) and Benin of the $14^{\text {th }}$ century AD. Did these accomplishments not happen when Europe was still in its Dark Ages? It is still open to reason that it was when Alexander the Great conquered Alexandria that Egypt's archival materials were taken to 
Greece, the foundation ground of Western academy. Is it in doubt that the same African Egypt gave birth to Imotep, the father of medicine who designed the Egyptian pyramid - one of the wonders of the world? Imotep was an accomplished scientist. Again was the great mathematician, Ahmes that is credited to have written the first mathematical textbook not an African (Aniakor 2011:15-16)? These great accomplishments were rubbished with colonial invasion. But, what has to be done? Throw away the child with the bathing bowl? Never! As Africa bewails its colonial past and disruptions, there is the need to re-examine Africa's indigenous knowledge in the light of the contemporary challenges facing the continent. The same manner the West invaded Africa and took away its best brains as slaves, took away its artifacts to re-model Europe, Africa must re-invent itself through industrialization. This might mean making use of the scientific models of the West. It is appropriate at this moment to re-conceptualize Africa and its indigenous knowledge.

\section{An Enslaved, Colonized Africa and Indigenous KnOWLEDge}

Africa is the second largest continent of the world, stretching to about eight thousand kilometers; it is surrounded by two oceans. The world first civilization is credited to Africa, initially showing great mastery over farming. Beginning in the $1500 \mathrm{~s}$, Africans were taken as slaves to the West. Their music and other cultures went with them. In America as an example, the African music became an important ingredient in the development of musical styles (Spielvogel 2005:100). As slaves, Africans would use work songs, sung to rhythmic patterns, to make their long work days less burdensome. At rest, others sang folk songs known as spirituals to lament the loss of motherland, and their freedom. Over the years, these African musical forms developed into new forms known as blues, gospel, jazz and ragtime. In the 20th century, Afro-American artists inspired new forms of music known as rock and roll and rap (Spielvogel: 100).

Africa was not only ravaged through trade in slaves; by 1884, Britain France, Germany and Belgium were engaged in the struggle for colonies in the continent. Portugal's claim over the Congo territory and river was supported by Britain but opposed by France and Belgium. Bismarck summoned a conference of all the European powers concerned with the scramble in Berlin. This was to avoid any open war. The main aim was to discuss the modalities for partitioning the continent. Lord Salisbury cynically explained the process of partitioning:

We have been engaged in drawing lines upon maps where no white man's feet have ever trod; we have been giving away mountains and rivers and lakes to each other, only hindered by small impediment that we never knew exactly where the mountains and rivers and lakes were (Barth 1966:343)

Thus, Africa following that scramble was effectively occupied by Europe. The scramble for Africa had important features that affected indigenous knowledge in the continent. First, the European colonial powers ignored ethnicity and divided ethnic groups into states controlled by different European powers. The Yoruba ethnic group on the one hand was divided between the French Dahomey and British Nigeria; the Kakwa on the other hand was divided between Uganda and the Southern Sudan. Thus African groups with identical cultural traditions were forcibly subjected to different languages, different modes of learning and laws. Second, Africa was forcibly linked onto the stage of world history; Africans, through the forced acculturation, started yearning for Western ways of life. The third but painful side of colonization was that many important African works of arts were stolen and in some instances destroyed. Benin is a good example to this episode. When the city was captured in 1897, many bronze plaques and ornaments from the Oba's palace were removed and some of these artifacts are displayed in parts of Europe.

European incursion into Africa affects what we are today labeling "Indigenous African knowledge system". Indigenous African knowledge system as a system of study is like other disciplines of study developed outside Africa, not within it. It is a system developed to the study of Africa, not necessarily by Africans. The context of this development was colonialism. This period shaped the organization of arts and social science studies in the Western Academy. These disciplines studied the European experience as universal human experience; as a field of study, Indigenous African Knowledge system that developed outside Africa, studies experience of color as an ethnic experience. Waters, a western analyst, did not hide his dilemma in studying and teaching African studies. He admitted that his new career in academia, "continues to have so little to do with Africa, despite" his "best efforts to make it 
so" (Waters 1995: 31). He confessed that the glaring weakness in any African related studies is the lack of empirical data combined with an over abundance of social theory.

Most of these theories were conceived in other continents in the context of their situations. Then they were imported to suite the African environment. Waters finally gave some admonition:

When researchers with preconceived ideas search for such situations hard enough, even in Africa, they can find them despite the fact that the basic assumptions of the model i.e. land scarcity and pursuit of individual advantages, are absent in much of sparsely populated rural areas. The results may be published, but to the field worker, the implied policy prescriptions... are typically not within the realm of possibilities (Waters 1995:32).

Another issue in the reconstruction of knowledge for Africa, which African indigenous system intends to advance, is ironic. It is epistemologically difficult that no educated African, whether a self proclaimed Afro-centric or a champion of African indigenous knowledge, has managed to completely strip himself or herself of western educational garb and its concomitant epistemology. This is particularly because Africa has been an intimate part of the history of this modernity and has paid most of its bills (Olaniyan 2005: 39-60).

From the foregoing, Africa remains a contested domain both academically and substantially. It is obvious that Africa as a concept does not necessarily mean the same thing to everyone. The same applies to Africa as an object of study. This sorry state makes Legum (1999) to differentiate between the Africa that is seen through the Western eyes and the one that is seen through the African eyes. From Legum's perspective, the former looks at Africa as an underdeveloped continent which has slid into economic corruption and ruin, despotic rule, coups and civil wars (Legum 1999:2). This definition of Africa is almost a truism, since the West has played a significant role in the invention of Africa by the arbitrary borders it bequeathed the continent. The latter is more problematic even for Legum, since no conscientious African scholar can specifically devote his or her time entirely to analyze the condition of one continent, but rather the conditions of many societies at different levels of political, social, and economic development" (Legum 1999:2). This problem is further magnified through the conceptions of the Western financial institutions that have devoted much energy to the African indigenous knowledge. For the World Bank, until quite recently, its concept of Africa is subSaharan Africa to the exclusion of South Africa, Namibia and North Africa. These areas were seen as low and middle income appendages of Europe and the Middle East. Whilst to UNCTAD and the ECA, the concept of Africa usually covers the entire continent. Arguably, a generalization about Africa does not arise. Africa is dependent on which 'Africa' is covered and by whom (Zeleza 1997: 292).

Without counting on the semantic differences of who the African is, it is obvious that Africa has through his creative capabilities been satisfying his needs from ages. No one taught the African to produce food, light fire and cook meals. Equally, Africans did not need instructors to conquer their environment by building and decorating their houses. Blacksmiths manufactured agricultural equipments like hoes and knives, boats were built to ease transportation in coastal and inland water ways, and made guns to protect themselves. The use of indigenous technologies presupposes an indigenous knowledge that was handed down from generation to generation.

Indigenous knowledge, equally seen as traditional or local knowledge is descriptive of the mass of knowledge and skills that has been developed outside the formal educational system (IFAD 2003). It is rooted in people's culture and is unique to a given environment or society. It demonstrates how societies make decisions as regards their food, security, health, music, education and natural resource management. Indigenous knowledge includes cultural heritage in the form of traditional stories, songs, dances and ceremonies that reflect beliefs related to spirituality, family, land and social justice (IFAD 2003).

Early African religious beliefs varied from place to place, though as Africans, they share common religious ideas. These ideas include the belief in a supreme deity and his messengers - minor gods or angels. Africa's indigenous knowledge is shown in its power of divination - western astrology and psychology - and the importance of ancestors. In early times, African works of art whether in painting, literature, music, to mention but these, served some religious and secular purposes. In the thirteenth and fourteenth centuries, Ife and Benin produced handsome bronze and iron statutes. The 
Benin sculptures include bronze heads, many of kings, and figures of various types of animals. Gin production was in abundance in Nigeria; gin distillation like other productive ventures, was outlawed by the colonial warlords to pave way to western brands of beverages. Economic problems confronting Africa today, the types that defy the western theories have understandably led to a resurgence of Africa's indigenous knowledge.

In the emerging global knowledge economy, Africa's ability to put together and mobilize knowledge capital is equally essential for sustainable development (Kurantin 2012). The basic component of Africa's knowledge system is understandably its indigenous knowledge. It encompasses African insights, experience and skills to maintain and possibly improve its livelihood (Ocitti 1973). African Indigenous knowledge is its social capital, the main asset to invest in the struggle for survival. To produce food, to provide shelter and thus achieve a modicum of control over its lives, is the basic thrust of African indigenous knowledge. Maurice Strong identifies three areas indigenous knowledge is important. The first beneficiaries are the indigenous peoples themselves that possess and live by the knowledge; the second are other people around the world who can learn to live sustainably in their own environments and finally the Eco-System - the earth- that would be treated carefully when diverse indigenous knowledge and values are followed more widely (Strong 1990). Despite these laudable benefits inherent in the African indigenous knowledge, the continent is still saddled with socio-economic problems. African economies are still being ran like private enterprises set up for profit. As presently constituted, Africa has the highest rate of youth unemployment and an unreliable power supply. Nigeria, the giant nation in the continent, is supposedly the sixth-largest producer of crude oil, yet she imports close to $80 \%$ of its refined petroleum products.

Are there some noticeable limitations in the presently constituted African indigenous knowledge systems? The answer is resoundingly positive. The issue is whether these limitations could be addressed through scientific discoveries already in place in the western world? This remains the main thrust of this essay. This paper proposes an African industrialization, a process that can only be achieved through the acquisition of scientific and technological skills. It is only in an industrial environment that Africa can resolve its contemporary socio-economic needs. While science is the study of nature, technology is its application in attending to man's needs. There is no denying the fact that scientific and technological innovations preceded Western industrialization. Industrialization as a matter of fact accounts for the western political dominance over the non Western societies.

That Europe began to project political power outward at about the time its innovations in scientific thinking and technological application were accelerating is not a coincidence...Imperial expansion and scientific/technological innovation share an underlying logic because both are derived from the same syndrome of attitudes (Abernethy 2000:190).

The continued scientific and technological discoveries and skills account for the widening dominance of the industrialized world. The United Nations understands the plight of Africa in this regard. As a result, the United Nations General Assembly, in 1989, decided that 20 November is remembered as Africa Industrialization Day. In that resolution, Africans and the nations of the world are to be mobilized to help industrialize Africa. Knowledge is a continuum and Africans must be prepared to acquire the relevant scientific knowledge that is needed for industrialization.

\section{AFRICAN INDIGENOUS KNOWLEDGE AND INDUSTRIALIZATION}

It is not enough to construe Africa in colonial terms. What is surprising is that after many years of independence from the colonial masters, Africa is yet to experience stable government, feed its populace without external charities, enjoy a self sustaining economy or even be known for its functional health programs. Oyebola gave an insightful picture in 1976:

As black peoples, we have no country to be proud of in terms of its great inventions and discoveries; its technical equipment and political power. No black country has successfully developed or adapted the technology of industrial civilization to assure its citizens a high standard of living... No black country has solved the problem of poverty among a great majority of its citizens. None has found any concrete solutions to the problem of poor nutrition, endemic diseases, inadequate basic education and infrastructural facilities (Oyebola 1976:10). 
Oyebola is not alone in this pathetic description of Africa and Africans. In his critical study of the African condition, Ali Mazrui outlines the following six paradoxes that are peculiar to the continent:

a. Africa is the first habitat of man but is the last to be made truly habitable.

b. Africans are not the most brutalized of peoples but are probably the most humiliated in modern history.

c. African societies are not the closest to the west culturally but have been experiencing the most rapid pace of Westernization this century.

d. Africa is not the poorest of the regions of the world in resources but it is the least developed of the inhabited continents.

e. Africa is not the smallest of the continents but it is probably the most fragmented.

f. Africa is the central of all the continents in geographical location but politically and to some extent militarily, it may be the most marginal (Mazrui 1980:23).

It is not easy to identify the root causes of Africa's sad condition when compared to other continents. It is even harder to prescribe all the ways out. Karl Marx, understands that as individuals express their lives, so they are; "what they are therefore coincides with their products, both with what they produce and how they produce" (Bottomore, ed 1964:27). It therefore follows that Africa in its post colonial era must be judged by the degree of its scientific and technological development. That is what today determines the people's quality of lives as well as the African personality.

There is the urgent need for Africans to transform their continent by scientific and technological knowledge to satisfy their needs and invariably be the controller of their destiny. It means that Africa must leave the domain of primitive tools, bows, arrows, spears, hoes and knives to the modern technological instruments. It is a shift from the traditional knowledge to a scientific and technological knowledge. That shift would require changing Africa's economic structure from the predominantly agricultural setting to the industrial; it would entail adding value to the vast reservoir of Africa's abundant raw material by processing them locally. In other words, it is a call for unfettered industrialization as the West experienced years back. Unlike the liberal and laissez-faire projections of some Western scholars, the industrialized countries had been supportive of their home grown manufacturing and industrial sectors. Analysts like Lin and Monga (2010) adduced some historical illustrations that attest to the fact that the industrialized countries had used the combination of trade, industrial and technological policies to favor their home grown companies. The United Nations General Assembly declaration that 20 November of every year must be celebrated as the Africa Industrialization Day must be understood in this light.

The General Assembly further nominated 1995 to 2004 as the International Decade of the Indigenous Peoples to address on the plight of the groups. The Second International Decade of the Indigenous Peoples was from 2005 to 2014. In addition, the UNESCO, (United Nations Economic and Social Council) established the United Nations Permanent Forum on Indigenous Issues (UNPFII) as its advisory body. Thus, UNPFIL is intended "to give indigenous peoples a unique voice within the United Nations system" quoting Mary Robinson, the UN High Commissioner for Human Rights (UN report 2002). Today, UNPFII has a permanent staff; meets yearly and studies problems faced by the indigenous peoples and bring such to the attention of the $\mathrm{UN}$ and other Inter-governmental Organizations.

One of the problems faced by the indigenous peoples particularly in Africa is how to reduce poverty; increase literacy; create jobs; enhance technical cooperation between industrialized and nonindustrialized nations; preserve and protect their environment. How can these noble objectives be achieved when the continent's indices of industrialization is nothing to cherish? As a matter of fact, poverty alleviation and creation of jobs are not dependent on the debates of politicians in the UN or the legislative houses of the industrialized nations.

Industrialization is no function of altruism. The plight of Africa's search for industrialization has both the negative and positive challenges. On the negative side is the realization that no country can help others to industrialize. This is particularly worrisome as Africa accounts for only one percent of the world manufacturing according to the 2013 Report by the United Nations Conference on Trade and Development (UNCTAD).This abysmal performance is against the continent's possession of the following: (a) 12 percent of the world's oil reserves (b) 40 percent of its gold (c) between 80 percent 
and 90 percent of world's chromium and platinum and lastly, it is the home to 60 percent of the world's underutilized arable land and has vast timber resources (UNCTAD 2013 Report).

On the positive side is that Africa's economic downturn is a source of challenge that can be alleviated through a well articulated industrialization strategy. Chinua Achebe's sarcasm about the indolent African country in search of an elusive technological transfer from the industrialized world is quite revealing:

A belief by backward people that some day without any exertion whatsoever on their part, a fairy-ship will dock in their harbor laden with every goody they have always dreamed of possessing (Achebe 1983:9).

In the alternative, Achebe canvassed for resourcefulness and ingenuity for which Africans were known before their colonial experience. In a nutshell, scientific resourcefulness and creativity is the panacea for a technological breakthrough, the sine qua non for industrialization.

I know enough history to realize that civilization does not fall down from the sky; it has always been the result of people's toil and sweat, the fruit of their long search for order and justice under brave and enlightened leaders (Achebe 1983:10).

Botswana and Mauritius are two African countries that have taken some reasonable measures towards this path of economic development. Botswana, a country that largely depends on the export of raw diamonds few years ago added some value by processing its rough diamonds. That saved the country six billion dollars that got lots of its unemployed youth out the streets and also boosted tourism (UNTCAD 2013 Report). Mauritius, a country dependent on export of sugar is today diversified through textiles, tourism, financial services and technology. The country's growth rate has remained 5 percent for many years. According to the World Bank Report, Mauritius per capita income also rose from $\$ 1,920$ to $\$ 6,496$ between 1976 and 2012,

Industrialization in Africa will entail a structural economic transformation from the predominantly agrarian to an industrial setting and this would amount to making use of the large reservoir of natural and agricultural resources. The call for industrialization is not new. The African governments since independence understood its importance. What went wrong was its external engineering, leading to policy summersaults. African governments started with the policy of import substitution, a genuine effort to industrialize and later was messed up by accepting the World Bank's Structural Adjustment Program (SAP), a policy that actually emphasized de-industrialization. As nations increased their share of manufactured exports, Africa still depends on extracting and exporting raw materials to other industrialized states. No industrially advanced country has left its shore open as Africa does. Asiatic countries and in particular Japan, has an industrial history that Africa can learn from. Japan as a non western society was humiliated in World War 11 and yet got its economic priorities right following the Great War.

\section{Adapting Japans Industrialization Process}

Japan is an island nation that since the $7^{\text {th }}$ century was ruled by emperors; from 1603 to 1867 it was shortly governed by military council titled shoguns. Though its landscape is about 80 percent mountainous, historically, the mountains were barriers to national integration, transportation and even economic development of its isolated areas. However, with technological breakthrough, the mountainous landscape has been overcome by bridges, tunnels and air transportation. Japan celebrates its mountains today in works of art, literature and beautiful national parks. From 1700, the Tokugawa shogunate closed Japan's borders to foreigners; for two hundred years; the period was a unifying one to the Japanese, as Japans indigenous educational and cultural supremacy was emphasized. The country's values can be deciphered from the national ethos that is taught to every Japanese child:

You, our subjects, be filial to your parents, affectionate to your brothers and sisters, as husbands and wives be harmonious, as friends true; bear yourselves in modesty, and moderation; extend your goodness to all; pursue learning and cultivate arts, and thereby develop intellectual faculties and perfect moral powers; furthermore, advance public good and promote common interests; always respect the Constitution and the laws; should emergency arise, offer yourself to the State; and thus guard and maintain the prosperity of our imperial throne (Ryusaku Tsunoda 1958). 
The Japanese leaders (Sat-Cho) that took over the mantle of governance after the shogunate system, in 1868 , had genuinely mistrusted the West, but realized that his country must change to survive. SatCho leaders embarked on a policy of reform (described as Meiji Restoration) that transformed Japan into a modern industrial nation. The Meiji government gave subsidies to local industries, provided training to the teeming population, improved transportation and communication, and started a new educational system that stressed applied sciences - all within the confines of the Japanese indigenous and cultural ethos. A unique feature of the Meiji model of industrial development was the close relationship between the government and private business. The government encouraged the development of new industries by providing to its entrepreneurial citizens with capital and other incentives. The moment an assisted enterprise or industry is up and doing, it is turned into private ownership. Even at that, the government continued to give an enabling environment to the industry's activities. The field of education witnessed some reforms. The Japanese leaders undertook universal education, including instructions on modern technology. The ministry of education established in 1871, set up schools in keeping with the American method. Foreign technologists, engineers, architects and art specialists were recruited to teach in the schools and many Japanese sent abroad to acquire more scientific and technological skills. Though Japan drew inspirations from the West, it placed emphasis on its indigenous culture that emphasized loyalty to the family, the community and deep respect to the Emperor-the guardian of the Japanese values.

From the foregoing, the following is associated with Japan's industrial success: (a) though modern technology was introduced into Japan, industrial administration ran in tandem with Japan's historical customs and attitudes; (b) looking beyond modern equipment and formal organization, the system of relationships are nearly similar to the traditional pre-industrial Japanese life. This is in contrast to formal factory organizations of the West; (c) the perception of the Japanese worker is radically different from that of the West. The loyalty of the worker to the industrial organization, the paternal methods motivating and rewarding the worker, the close involvement of the company to the overall welfare of the individual have parallels to Japan pre-industrial indigenous life. In the West, many things that affect the worker [such as births and death] are classified as personal or private affairs of the worker. These three observations are relevant to Africa in its match towards industrialization. Japan did not have to jettison its indigenous knowledge system, no matter the attractions of the industrial West. It is against this backdrop that Abegglen made an incisive remark, the type that can help the African countries:

Japan's extraordinary history of industrialization remains a unique record of effective social change, compelling the attention of those concerned with problems of industrialization and economic development in non-Western societies. Japan strode from hard held Asian insularity to a central role in world industry, world trade, and world power relations in a single, explosive burst of energy and remains the singular case of non-Western industrialization. The outlines of the story are familiar; its implications for present attempts effectively to bring about development in other countries are evident (Abegglen, 1970:565).

\section{CONCLUSION}

This paper examines the usefulness of Africa's indigenous knowledge and the quest for industrialization. Though Africa remains a contested concept, not meaning the same thing to everyone, yet its historic past has been distorted with foreign incursion and domination. Thus, Africa's ingenuity associated with technical breakthroughs was distorted. Nonetheless, it is no use blaming the past, particularly now that the continent is fraught with myriads of problems. Africa can therefore take a cue from another non-western society that successfully industrialized. The time is gone for Africa to depend on foreign charities. There is need for an African solution to African problems. Africa's ingenuity can be re-invented in its match to industrialization. Indigenous knowledge that emphasizes unique African customs and values can assist in the continent's match towards industrialization. As already attested, myriads of economic problems confronting Africa today, the types that defy the western theories have understandably led to a resurgence of Africa's indigenous knowledge. But there are steps to be taken in the preservation of such knowledge.

The steps in many indigenous knowledge projects involve identifying the materials to be preserved and then capturing them in a special form so as to share, document and be re-used by the communities or individuals. Preserving, describing and disseminating such knowledge remain a challenge till date. 
Because indigenous knowledge is traditionally oral, the transmission, documentation and preservation of the knowledge are necessary; this clarion call is coming amidst cultural diffusion and infiltrations particularly from the non-African worlds. The possibility of the indigenous knowledge to be replicated scientifically is a sine qua non of the industrialization process. Japan is great industrially for not rejecting its indigenous values in its strides for industrial wellness. Africa should re-invent its indigenous knowledge system and must adopt skills acquisition centers, training and development in work places; full employment policy must be encouraged to increase the workers scientific capabilities. This is the sine qua non for Africa's industrialization.

\section{REFERENCES}

[1] Abernethy D. B (2000) the Dynamics of Global Dominance: European Overseas Empires 14151980, New Haven: Yale University Press.

[2] Aniakor C. C (2011) "Strategies for Human Capital Development in Nigeria: A Perspective" in Egonwa OD (ed) The Humanities and Human Capital Development, Abraka: The Humanities, Delta State University.

[3] Barth H, (1966), Travels and Discoveries in North and Central Africa ... in the years 18491855, London, 1857, centenary edition.

[4] Berman, E. H. (ed.) 1975, African Reactions to Missionary Education, New York: Teachers College Press.

[5] Bottomore, T.B. (ed.) 1964. Karl Marx- Early Writings, New York: McGraw Hill.

[6] Bourke, J.T (2007) International Politics on the World State $11^{\text {th }}$ edition, New York: Mc GrawHill.

[7] Achebe, C. (1983) the Trouble with Nigeria, Enugu: Fourth Dimension Publishers.

[8] IFAD (2003) Indigenous Peoples and Sustainable Development, Roundtable Discussion Paper for the Twenty-Fifth Anniversary Session of IFAD's Governing Council.

[9] Jones, J. J. (1925) Education in East Africa, New York

[10] Kraemer, H. (1938) The Christian Message in a Non-Christian World, London: The Edinburgh House Press.

[11] Kurantin, N. Y.D. "Indigenous Knowledge, Industrialization and Resource Management in the face of Globalization" Ghana Institute of Management and Public Administration, DOI: 10.7763/IPEDR. 2012. V54. 48

[12] Legum, C. (1999) Africa since Independence, Bloomington, Indiana University Press. New York Times, (NYT) March 31, 1996.

[13] Lin J Y and C. Monga (2010) Growth Identification and Facilitation The Role of the State in the Dynamics of Structural Change, The World Bank.

[14] Lopez, C, (2014) “Africa and the Myth of Industrialization" Ventures Africa

[15] Mazrui, A. A. (1980) the African Condition: The Reith Lectures, London: Heinemann.

[16] Ocitti, J. P. (1973), African Indigenous Education as Practised by the Acholi of Uganda, Nairobi: East African Literature Bureau.

[17] Olaniyan, T. (2005) "Post-Modernity, Post Coloniality and African Studies" in Z, Mugubane (ed), Post-Modernity, Post Coloniality and African Studies, Asmara, Eritrea, Africa World Press, Inc: 39-60.

[18] Oyebola, A. (1976) Blackman's Dilemma, Lagos: Board Publishers Ltd.

[19] New York Times, March 31, 1996.

[20] Ryusaku T, et el (eds) 1958, Sources of Japanese Tradition, New York, Columbia University Press.

[21] Strong, M. (1990) the Gaia Atlas Of First Peoples: A Future For The Indigenous World, New York: Doubleday.

[22] Spielvogel, J. J (2005) World History Modern Times, New York: Mc Graw Hill.

[23] United Nations High Commissioner for Human Rights Press Release, May 12, 2002.

[24] Waters T. (1995) "Africanists and the Challenge of the Mission Veranda", Issue: A Journal of Opinion, 23 (1): 31-34.

[25] Zeleza, P.T. (1997) Manufacturing African Studies and Crises, Dakar, CODESRIA. 


\section{AUTHOR'S BIOGRAPHY}

Dr Adigbuo, Ebere Richard, is a Senior Lecturer in the Department of History and International Studies, Delta State University, Abraka Nigeria. He studied political science in Nigeria's premier university- University of Ibadan- and in 2005 completed his doctoral program in Political Studies, University of Johannesburg, South Africa. His research interest is in his field of specialization: International Relations and Foreign Policy Analysis. 